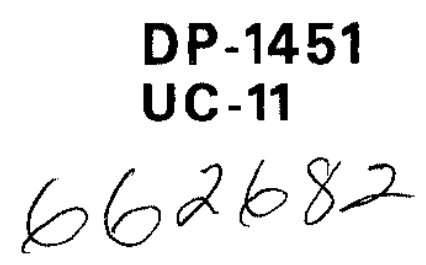

\title{
TORNADO ACTIVITY AT SRP DURING 1976
}

D. W. PEPPER

J. F. SCHUBERT
TIS FILEX

RECORD COPY

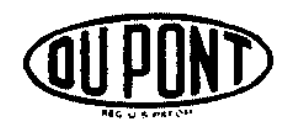

SAVANNAH RIVER LABORATORY AIKEN, SOUTH CAROLINA 29801 


\section{NOTICE}

This report was prepared as an account of work sponsored by the United States Government. Neither the United States nor the United States Department of Energy, nor any of their contractors, subcontractors, or their employees, makes any warranty, express or implied or assumes any legal

liability or responsibility for the accuracy, completeness or usefulness of any information, apparatus, product or process disclosed, or represents that its use would not infringe privately owned rights.

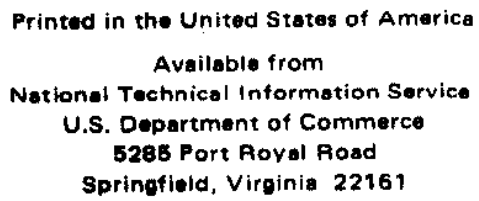

Price: Printed Copy $\$ 4.00$; Microfiche $\$ 3.00$ 


\section{TORNADO ACTIVITY AT SRP DURING 1976}

by

D. W. Pepper

J. F. Schubert

Approved by

T. V. Crawford, Research Manager

Environmenta1 Transport Division

Publication Date: July 1978

E. I. DU PONT dE NEMOURS AND COMPANY

SAVANNAH RIVER LABORATORY

AIKEN, SOUTH CAROLINA 29801

PREPARED FOR THE U.S. DEPARTMENT OF ENERGY UNDER CONTRACT AT(07-2) 1 
Tracks of three small tornadoes were confirmed on the site of the Savannah River Plant during 1976. Only minor damage to buildings and vehicles was experienced. The tornadoes were rated F1 on the Fujita-Pearson scale. Synoptic weather conditions from the National Weather Service and from the SRP seven-tower data system were recorded. 
Introduction

Tornado Severity and Incidence 5

Tornadoes of May 28, $1976 \quad 6$

$\begin{array}{ll}\text { Synoptic Weather Conditions } & 6\end{array}$

$\begin{array}{ll}\text { First Tornado } & 7\end{array}$

Second Tornado 9

Tornado of Ju1y 2, 1976

$\begin{array}{lr}\text { References } & 10\end{array}$ 
1. Surface Data for Bush Field (Augusta, GA) May 28, $1976 \quad 8$

2. Alerts for Tornadoes of May 28, $1976 \quad 8$

1. Tornadoes in the US From 1930 to 1974

2. Tornadoes in Georgia and South Carolina From
1950 to 1971

3. Synoptic Weather Conditions for May 28, $1976 \quad 13$

4. Synoptic Weather Conditions for May 29, $1976 \quad 14$

5. Tower Data for Period When a Funnel was Over D Area 15

6. Tower Data for Period When a Tornado Struck Central Shops Area 16

7. Tower Data for Period When a Funnel was Over the
Aiken Barricade

8. Confirmed Tornado Tracks at SRP 18

9. Building Damage From Tornado of May 28, $1976 \quad 19$

10. Tree Damage From Tornado of May 28, 197620

11. Tree Damage From Tornado of July 2-4, 1976 


\section{INTRODUCTION}

Three small tornadoes struck the Savannah River Plant (SRP) in 1976. This is the first time in the 25-year history of the plant that tornadoes have been observed and confirmed within the 300 square mile area of the plant site.

The first tornado, which was observed at 1530 EDT on May 28, did minor damage to storage facilities, motor vehicles, and trees. Production facilities were not damaged, and there were no injuries. The second tornado occurred five hours later and did only minor damage to trees. The third tornado, which struck during the period July 2 to July 4, 1976, was not observed, but is presumed on the evidence of damage to trees. The damage was investigated following each strike.

The purpose of this report is to document these tornado strikes and the associated weather conditions. The assessment of all tornadoes striking SRP is of vital importance in learning the effects of tornadoes on the immediate environment. Consequences resulting from a tornado striking a nuclear facility at SRP are discussed in Reference 1. Categorization of tornadoes is necessary if the prediction of damaging tornadoes is to be improved. Synoptic weather conditions prior to two of the strikes are discussed, and the emergency alerts given by the SRP Emergency Operating Center (EOC) and the National Weather Service are 1isted. Tornado damage is also analyzed and the tornadoes are classified by the Fujita-Pearson scale $(2,3)$.

\section{TORNADO SEVERITY AND INCIDENCE}

Tornadoes are violent whirlwinds capable of inflicting severe localized damage. Most tornadoes appear as sma1l rope-like funnels, occurring along fronts or in large clusters of thunderstorms. These storms are generally short-lived and do minimal damage. Large tornadoes have cone-shaped funnels and generally occur only in isolated thunderstorms. While they comprise only three percent of all tornadoes, large tornadoes are responsible for nearly all severe damage and tornado fatalities.

In the Southeastern region of the United States, the greatest number of tornadoes occur in early spring and late summer. Over 50 percent occur from March through June. In South Carolina, the months having the greatest frequency are April and May. A smaller maximum in August and September comprises about 20 percent of the total and is due mainly to tornadoes spawned by hurricanes and by waterspouts. Fifteen percent occur during October through January. According to Purvis (4), one or two tornadoes can be 
expected in South Carolina during April and May, while March, June, July, August, and September generally will have one each. In 1973, eleven tornadoes occurred in May. Tecson (5) reports that most tornadoes in the Southeast occur between $1 \overline{0} 00$ and 2000 EDT. However, a medium-sized tornado struck Columbia, South Carolina, at 0330 EDT on May 15, 1976.

Although more than 300 tornadoes have occurred in South Carolina in the last 60 years, only within the last 25 years have tornado strikes been analyzed in detail. Tracks of confirmed tornadoes in the United States from 1930 to 1974 (6) are shown in Figure 1. Figure 2 shows tracks of tornadoes in Georgia and South Carolina (7). The areas of Georgia and South Carolina within 100 miles of $\overline{\mathrm{R} P}$ show a low incidence of tornado strikes. However, this area has a relatively low population density, and more tornadoes could have passed unobserved and unreported.

The probability of a tornado striking SRP has been calculated by Cooper (8) and McDonald (9). Based upon their analysis and using the relative area of $S \bar{R} P$ compared to the area of Georgia and South Carolina, the recurrence interval of a tornado striking SRP is once every 10 years. Although funnels had been observed above SRP at various times between 1952 and 1975, no tornado strikes had been confirmed. Confirmation of a tornado long after the strike is impossible because of deterioration of the damage area due to ice storms, tree damage from thunderstorm downdrafts, and removal of downed or damaged trees by forestry cutting and cleanup.

\section{THE TORNADOES OF MAY 28, 1976}

Two tornadoes struck SRP on May 28, 1976. The first tornado touched ground at approximately 1530 EDT southeast of Central Shops and moved northwestward toward 200-F Area. The tornado reached 200-F Area at 1535 EDT and lifted. The second tornado occurred at approximate1y 2030 EDT and moved in a westerly direction beginning $1 / 8$ mile west of Highway 8 on Highway 8-1.

\section{Synoptic Weather Conditions}

Figures 3 and 4 are surface charts for the hours between 0800 EDT on May 28, 1976, and 0800 EDT on May 29, 1976, respectively. The charts showed a low pressure area to the west of SRP with an occluded front. This area became a static front curving through southern Alabama and Georgia and out to sea. The high pressure area was located to the northeast about $500 \mathrm{~km}$ east of New York. Surface winds during the storm period were from the southeast. The 500 and $700 \mathrm{mb}$ winds were from the south-southwest. 
Table 1 shows the surface temperature, dew point, wind speed, and wind direction from 1400 to 2000 EDT obtained from the

National Weather Service Station at Bush Field, Augusta, Georgia. Temperatures and wind speeds are shown in Figures 5-7 during the times that funnels were observed above SRP and during the tornado strike at Central Shops. Temperatures and wind velocities at seven levels were obtained from the instrumented WJBF-TV tower. Wind velocities and direction over SRP were obtained from the SRP seven-tower system (10). Table 2 lists the alerts given by the Emergency Operating Center (EOC) for SRP and the National Weather Service at Bush Field for the Central Savannah River Area. Directions and path lengths of both torradoes are shown in Figure 8 .

\section{First Tornado}

A funnel aloft over the 400 Area was reported at 1435 EDT. The National Weather Service in Columbia, South Carolina, was notified immediately. A radar scan of the area north of SRP was subsequently begun by Columbia weather personnel. At 1530 EDT, the EOC reported a tornado in progress at Central Shops. At 1533 EDT, the National Weather Service in Columbia was notified that a tornado was moving from longitude $87^{\circ}-38^{\prime}$ and latitude $33^{\circ}-15^{\prime}$ (Central Shops parking lot) in a northwesterly direction. A radar scan north of SRP was again undertaken but was unable to detect the storm. The tornado dissipated at 1535 EDT at F Area. The damage following the tornado strike was investigated immediately.

In the Central Shops area, several large wooden pallets were observed to be lifted to 100 feet above the ground and then to disintegrate. A pine tree was seen in the vortex 75 feet above the tops of the trees northwest of the Central Shops area. Windows were partially or totally broken out of eighteen private automobiles. Buildings in the Central Shops area suffered light damage. The width of maximum damage was approximately 60 feet in the Central Shops area.

As the tornado moved from Central Shops toward 200-F Area, many trees were either snapped off 6 feet above the ground or uprooted. The vortex, still observed by Central Shops personnel, appeared to become more distinct and cylindrical in shape with a larger diameter. The damage width in the forest northwest of Central Shops reached a maximum of 300 feet. Medium sized hardwood trees were uprooted. Small trees were probably not damaged because of their relatively small load carrying profiles.

The 200-F Area suffered minor damage. Several large hardwood trees were uprooted and several pine trees were snapped 6 to 8 feet above the ground. Corrugated tin roofs of three small structures were blown off. A small section of one roof was found 300 feet to the northwest of the structure.

$$
-7-
$$


TABLE 1

$\begin{array}{lllll}\text { Surface Data for Bush Field (Augusta, GA) May 28, } 1976 \\ \text { Time, EDT } & \text { Temp, }{ }^{\circ} \text { F } & \text { Dew Point } & \text { W/s, Kts } & \text { W/Dir. } \\ 1400 & 69 & 67 & 09 & 100 \\ 1500 & 73 & 69 & 12 & 120 \\ 1600 & 70 & 67 & 06 & 100 \\ 1700 & 71 & 68 & 11 & 060 \\ 1800 & 69 & 66 & 12 & 140 \\ 1900 & 67 & 65 & 10 & 080 \\ 2000 & 67 & 65 & 12 & 110\end{array}$

\section{TABLE 2}

Alerts for Tornadoes of May 28, 1976

EOC Alerts for SRP

1431 EDT Tornado Watch

1530 EDT Tornado Warning

1535 EDT Tornado Warning

2043 EDT Tornado Watch
Funnel sighted over 400 Area

Tornado observed at Central Shops

Tornado observed at 200-F entrance

Funnel observed SE over Alken Barricade, Hwy 19

\section{NWS (Bush Fleld) Alerts for CSRA}

1408 EDT Tornado Warning

1515 EDT Heavy Severe Thunderstorm Warnings

1538 EDT Tornado Warning

1635 EDT Heavy Severe Thunderstorm Warnings

1950 EDT Tornado Watch
Tornado reported 20 miles SE of Augusta moving $\mathrm{N}$ at $30 \mathrm{mph}$

Tornado reported 5 miles $E$ of Bush Field moving $\mathrm{N}$ at $30 \mathrm{mph}$

Tornado reported in Centra1 Savannah River Area (unconfirmed location and direction)

2303 EDT Tornado watch Ended 
Based on damage to trees and on debris adjacent to the structures in Central Shops and 200-F Area, the tornado was rated F1 according to the Fujita-Pearson scale $(2,3)$. This rating corresponds to a windspeed of less than $120 \mathrm{mph}$. The damage path length was approximately 5 miles long and its maximum width of damage was approximately 100 yards.* Building damage at the entrance to F-Area is shown in Figure 9. Tree damage between Central Shops and F-Area is shown in Figure 10.

\section{Second Tornado}

Patrol observed a funnel aloft at 2043 EDT and later investigation of ground damage confirmed the tornado strike at a location west of Highway 8 near Highway $8-1$. The tornado was spawned from a thunderstorm cell east and north of the first tornado. Damage was done only to the forest. Some trees were snapped about 6 feet above the ground, some were uprooted, and many were debarked. The path length was $1 / 2$ mile and the width was approximately 400 feet at the widest point. The tornado was given a rating of $\mathrm{Fl} . * *$

The tornado which struck SRP at 2043 EDT was not detected by the radar of the National Weather Service in Columbia. Earlier, at 1721 EDT, a hook echo (a possible tornado indication) was observed north of SRP. However, there was no visual confirmation and no ground damage was discovered.

The two tornadoes that struck SRP on May 28, 1976 were very unusual in direction. Both tornadoes moved in a west-northwesterly direction. Nearly all other tornadoes that have been observed and recorded in the Southeast have moved in a northeasterly direction.

\section{TORNADO OF JULY 2, 1976}

On July 2, 1976, synoptic weather reports indicated the likelihood of severe weather and possible tornado development in the CSRA for July 2 through 4, 1976. Although no tornadoes were observed at SRP during this time, fresh damage to trees was noticed northeast of the old Savannah River Ecology Laboratory (SREL) on July 5, 1976. This damage was investigated on the afternoon of July 5, 1976. Based on the appearance of the damage, a tornado track was confirmed $1 / 2$ mile northeast of SREL. Later investigation of the damage near 700 Area suggested that the tornado originated west of A Area and either skipped or lifted until striking near SREL. Because tree damage was very fresh, the tornado was considered to have developed between July 2 through 4 ,

* The Fujita-Pearson rating on this tornado was actually F1-P2-P2. The first P2 denotes a path length of 3.2 to 9.9 miles and the second P2 denotes a damage width of 56 to 175 yards.

** F1-P0-P2 where Po denotes a path length of 0 to $1.0 \mathrm{mile}$. 
1976. This tornado was given a rating of $\mathrm{Fl}$. The damage east of SREL is shown in Figure 11 .

An aerial survey was made of SRP several weeks after the strikes. However, the damage paths had already been cleaned up by the Forest Service, and the path lengths and radii of damage could not be assessed accurately.

The tornadoes that struck SRP in 1976 were not of great consequence in themselves. However, they provided an opportunity to record data that may be useful in predicting trajectories and intensities of future storms. Warnings well in advance of a storm could alleviate the consequences of a severe tornado strike.

\section{REFERENCES}

1. D. W. Pepper. Dispersion of Sma1l Particles in a Tornado. ERDA Report DP-1387. E. I. du Pont de Nemours \& Company, Savannah River Laboratory, (1975).

2. T. T. Fujita. "F-Scale Classification of 1971 Tornadoes." SMRP Research Paper No. 100, (1972).

3. T. T. Fujita. "Tornadoes Around the World." Weatherwise 26, 56-62 (1973).

4. J. C. Purvis. "Tornado Facts for South Carolina." Weather Service Forecast office, West Columbia, S.C. (1976).

5. J. J. Tecson. "Characterization of 1965 Tornadoes by their Area and Intensity." SMRP Research Paper No. 94, (1972).

6. T. T. Fujita. "Tornadoes in the United States from 1930-1974." Univ. of Chicago, Dept of the Geophysical Sciences (1976).

7. I. Spikler. Tornado Uind Damage Probability and Recurrence for the Savannab River S1te. Report 0367-025-27, Dames \& Moore, Bethesda, MD (1973).

8. R. E. Cooper. "Tornado Occurrence Probabilities at SRP." (Private communication).

9. J. R. McDonald. "Development of Windspeed Risk Models for the Savannah River Plant Site." Texas Tech University, Institute for Disaster Research (1976).

10. C. D. Kern, R. A. Mueller, and J. M. Sandler. "A PDP-ll-Based System for Meteorological Data Acquisition and Emergency Response." Proc. Spring DECUS Symposium, Atlanta, GA, May 25-28, 1976. Report CONF-760559-2 (1976). 


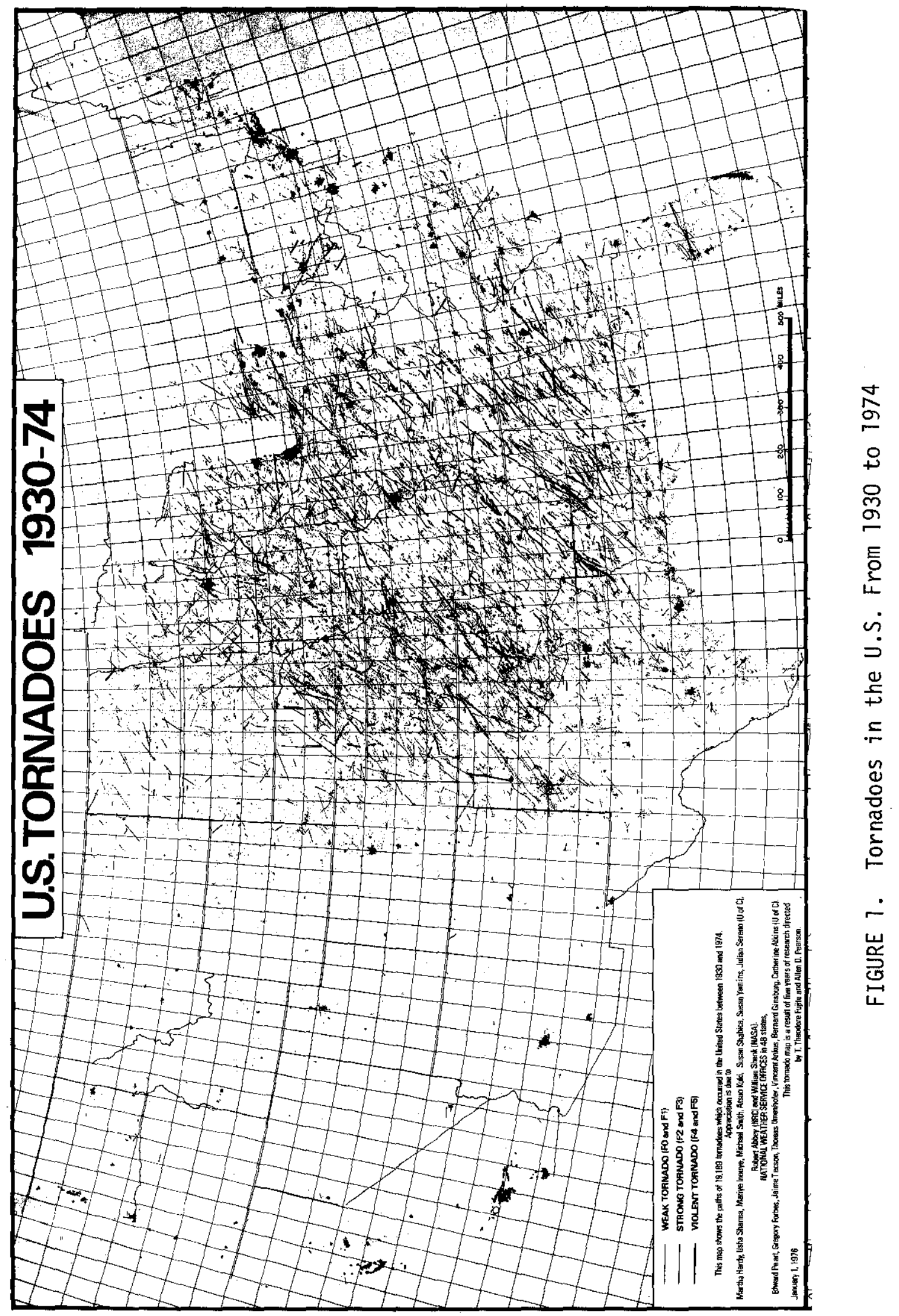




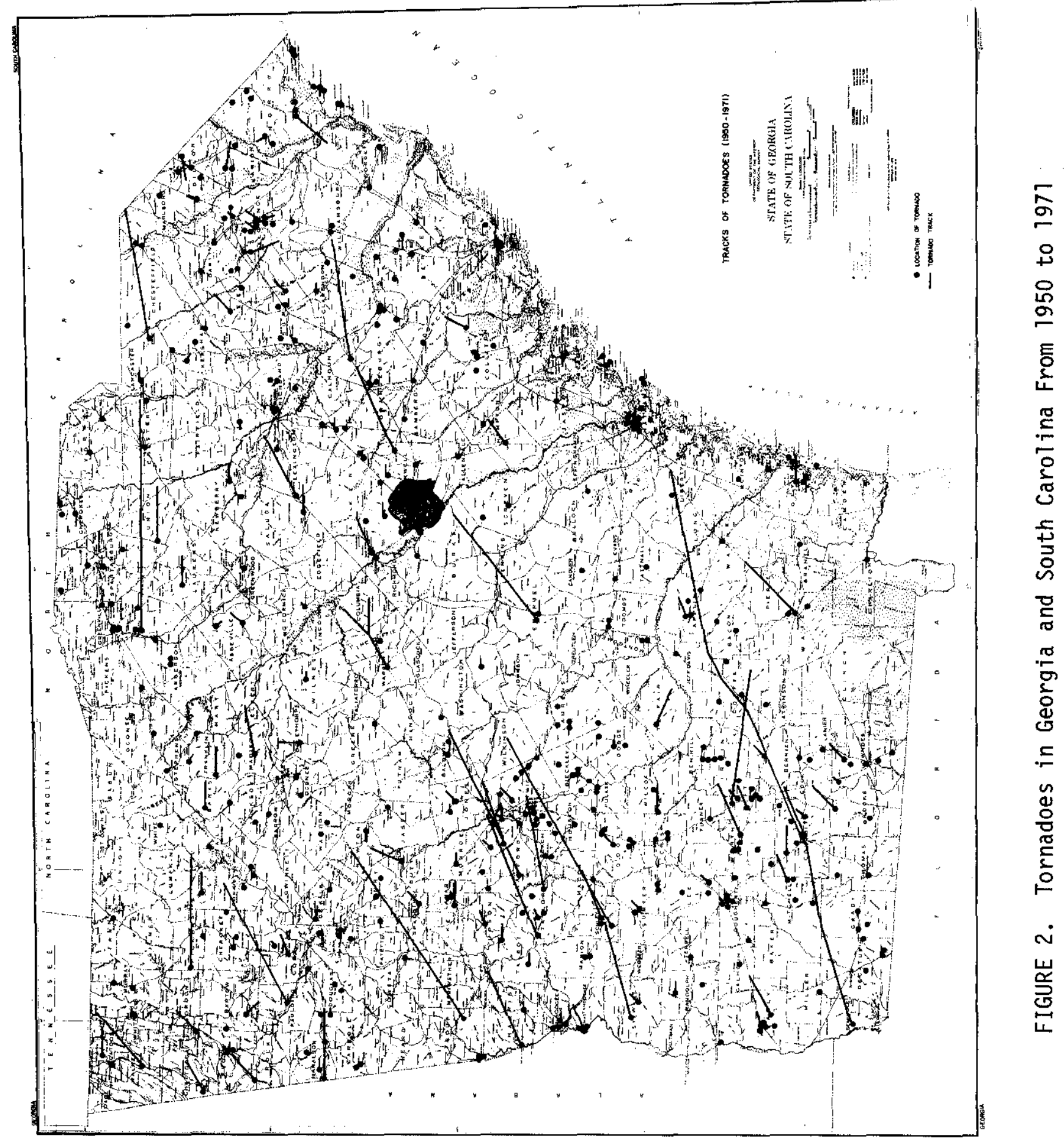




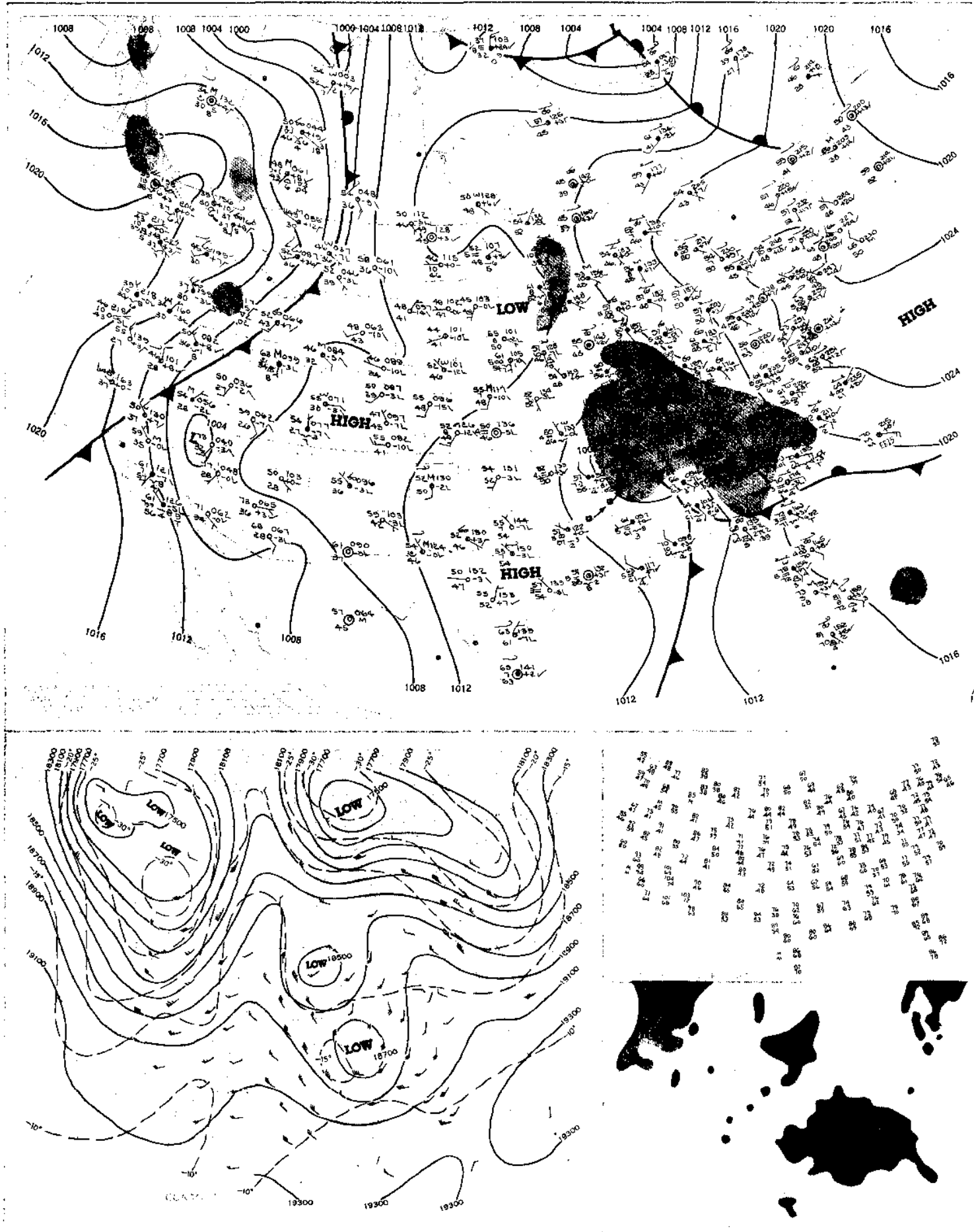

FIGURE 3. Synoptic Weather Conditions for May 28, 1976 


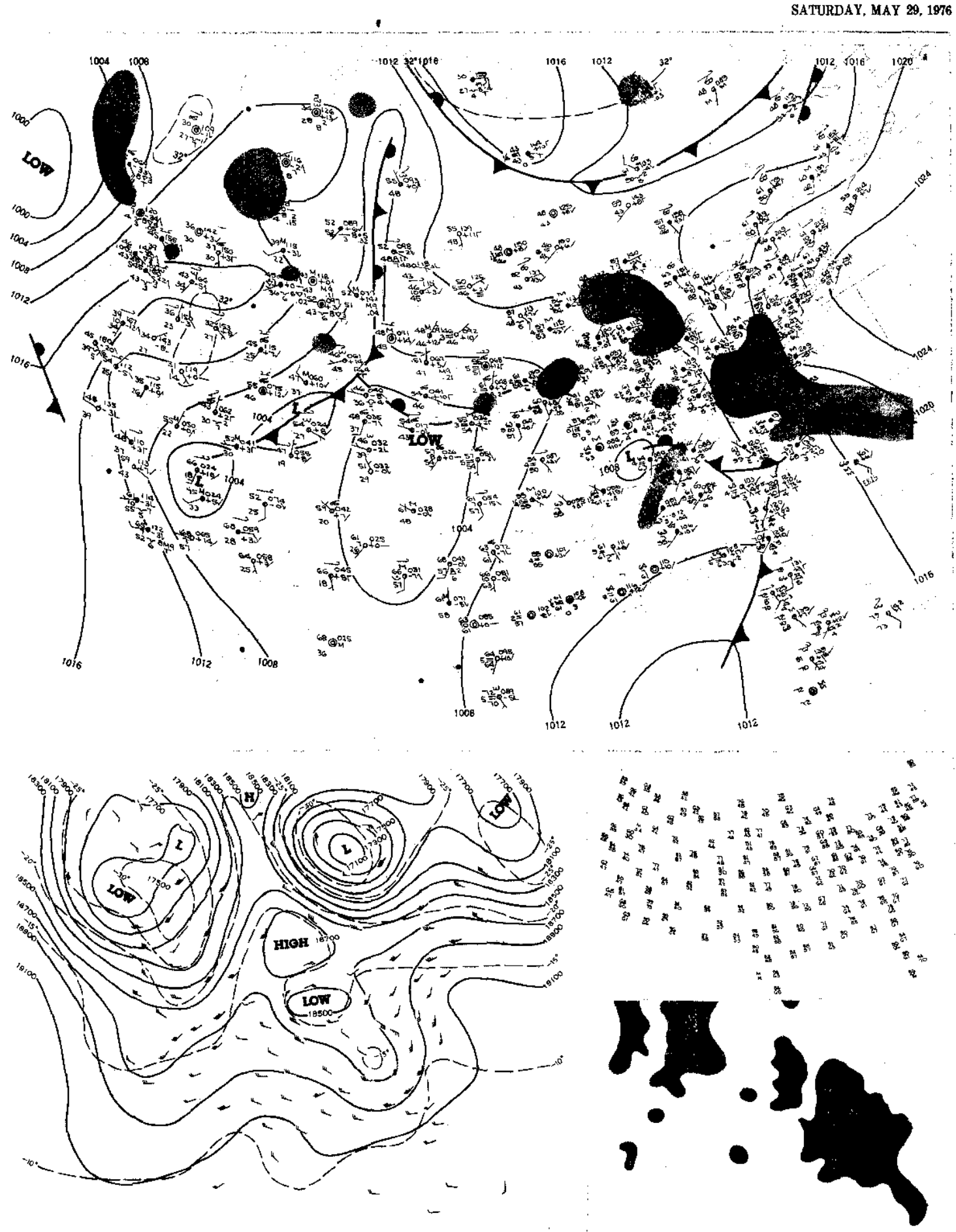

FIGURE 4. Synoptic Weather Conditions for May 29, 1976 

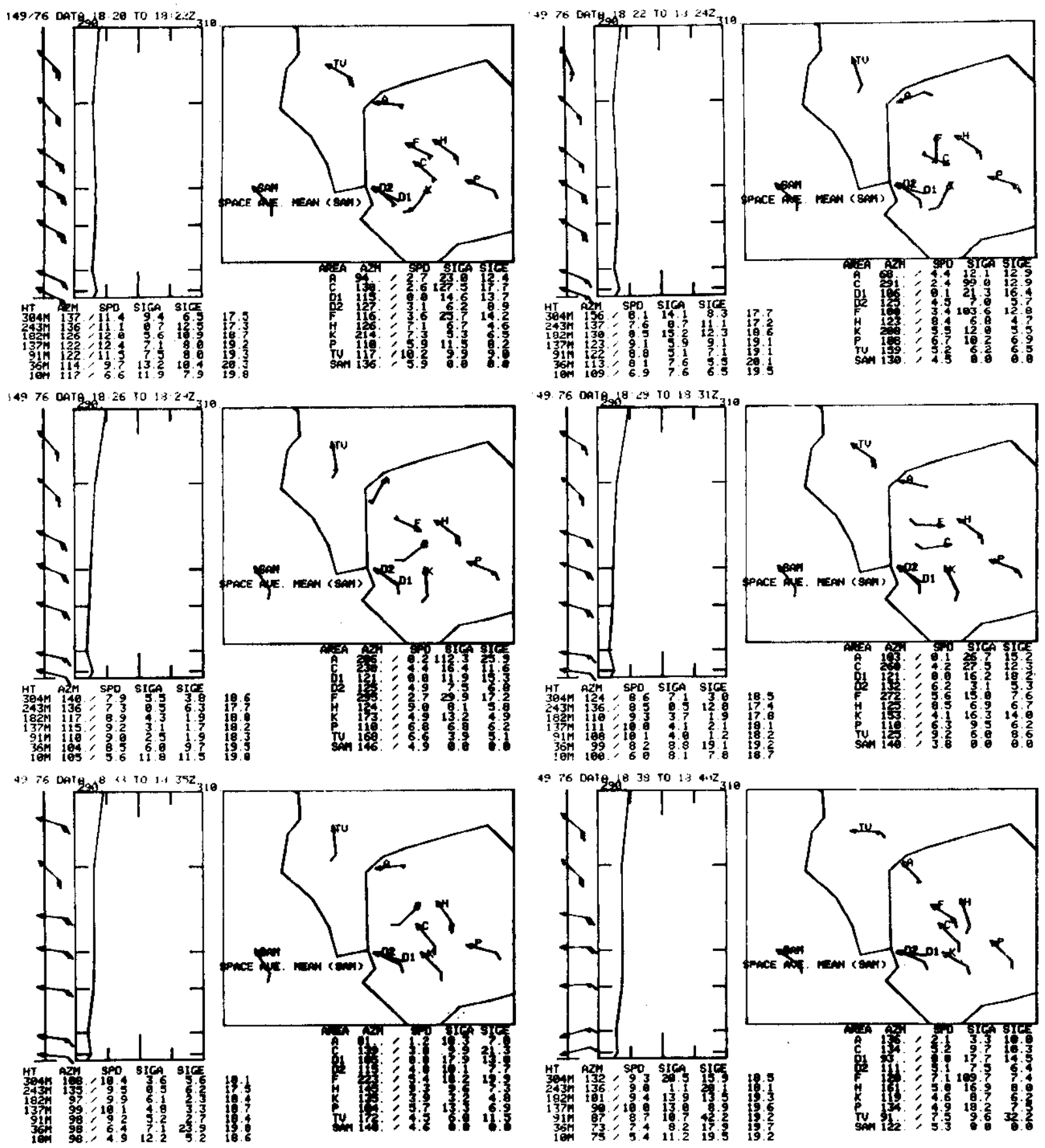

FIGURE 5. Tower Data for Period When a Funnel was Over D-Area 

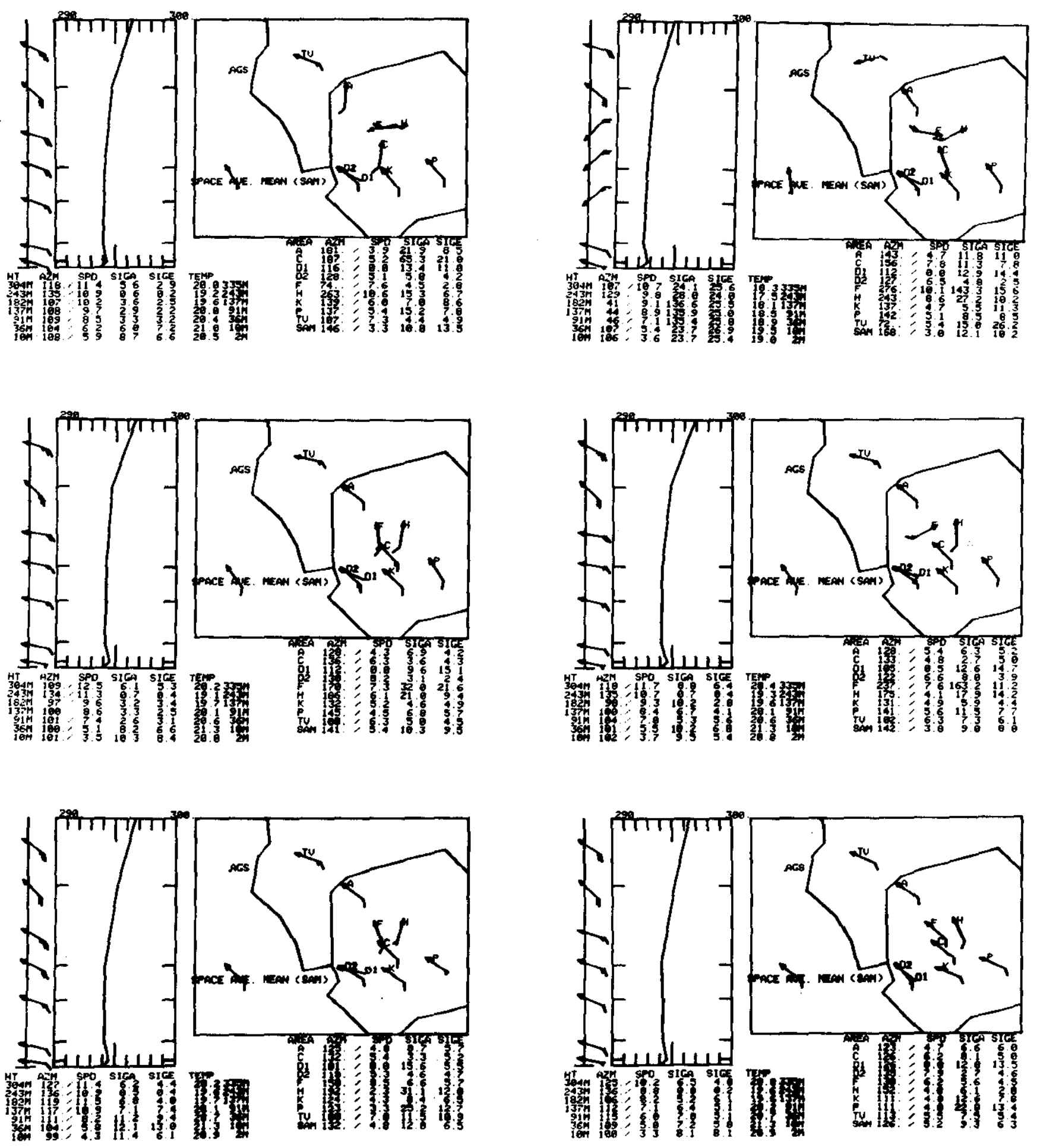

FIGURE 6. Tower Data for Period When a Tornado Struck Central Shops Area 

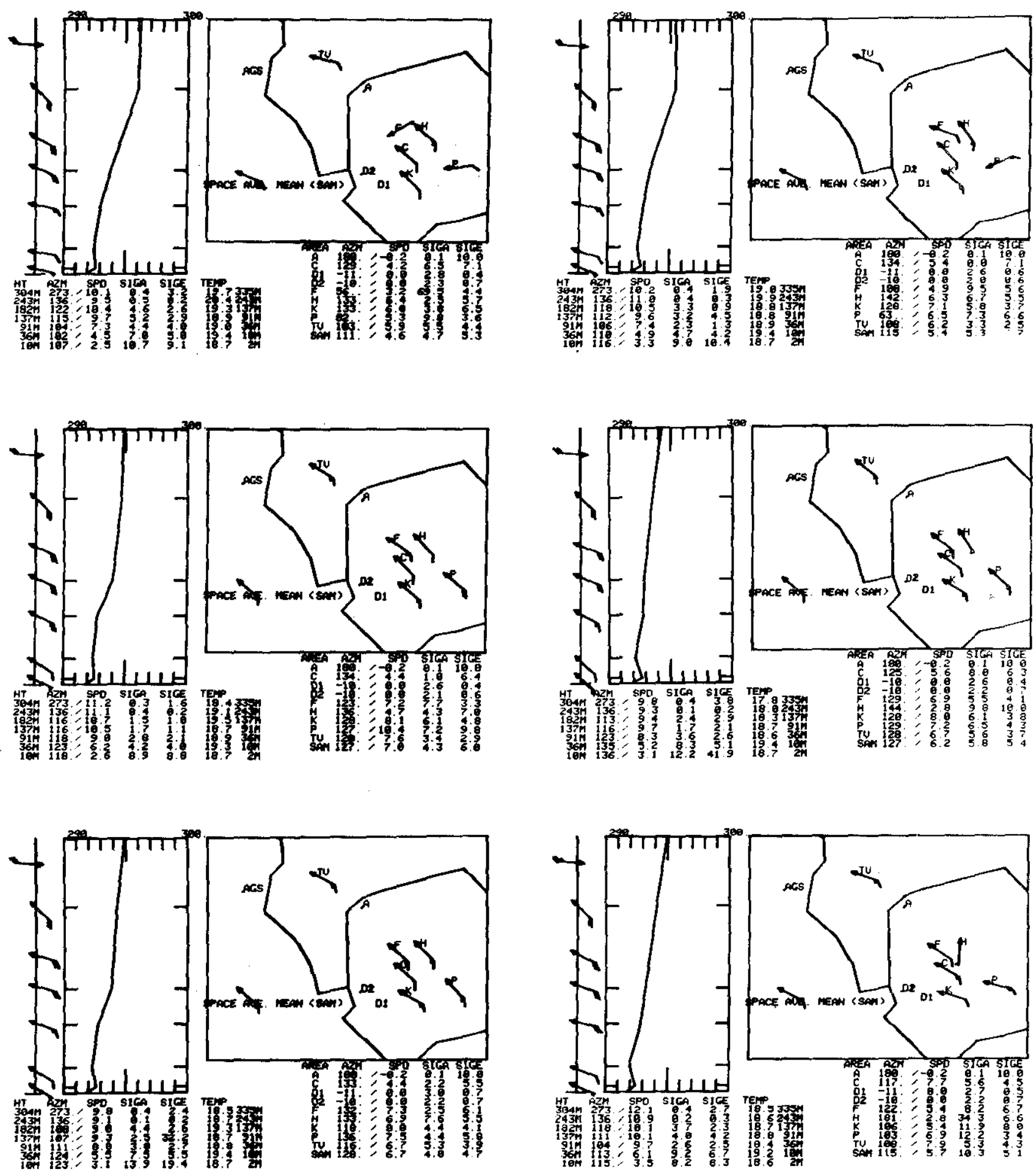

FIGURE 7. Tower Data for Period When a Funnel was Over the Aiken Barricade 


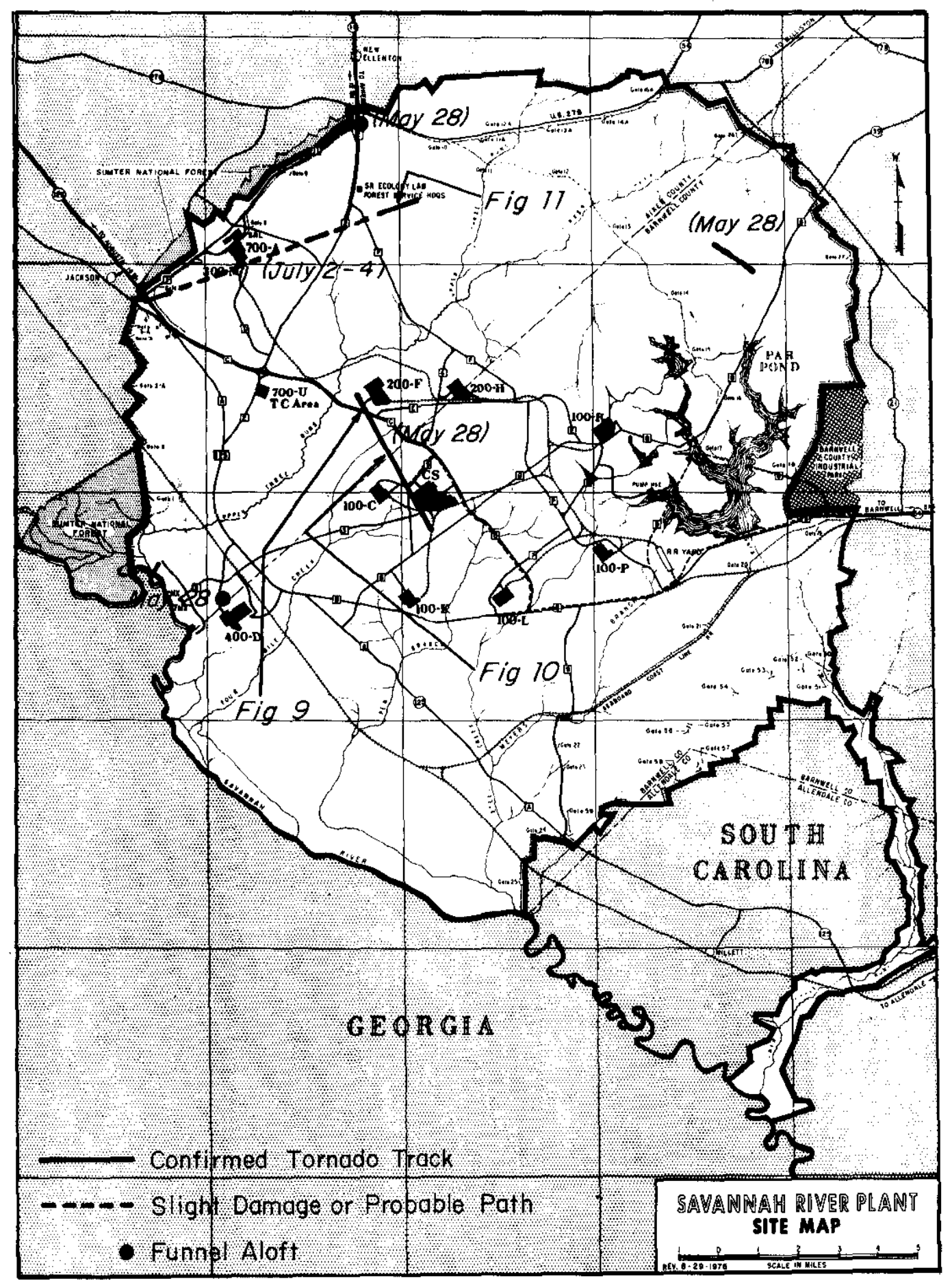

FIGURE 8. Confirmed Tornado Tracks at SRP 

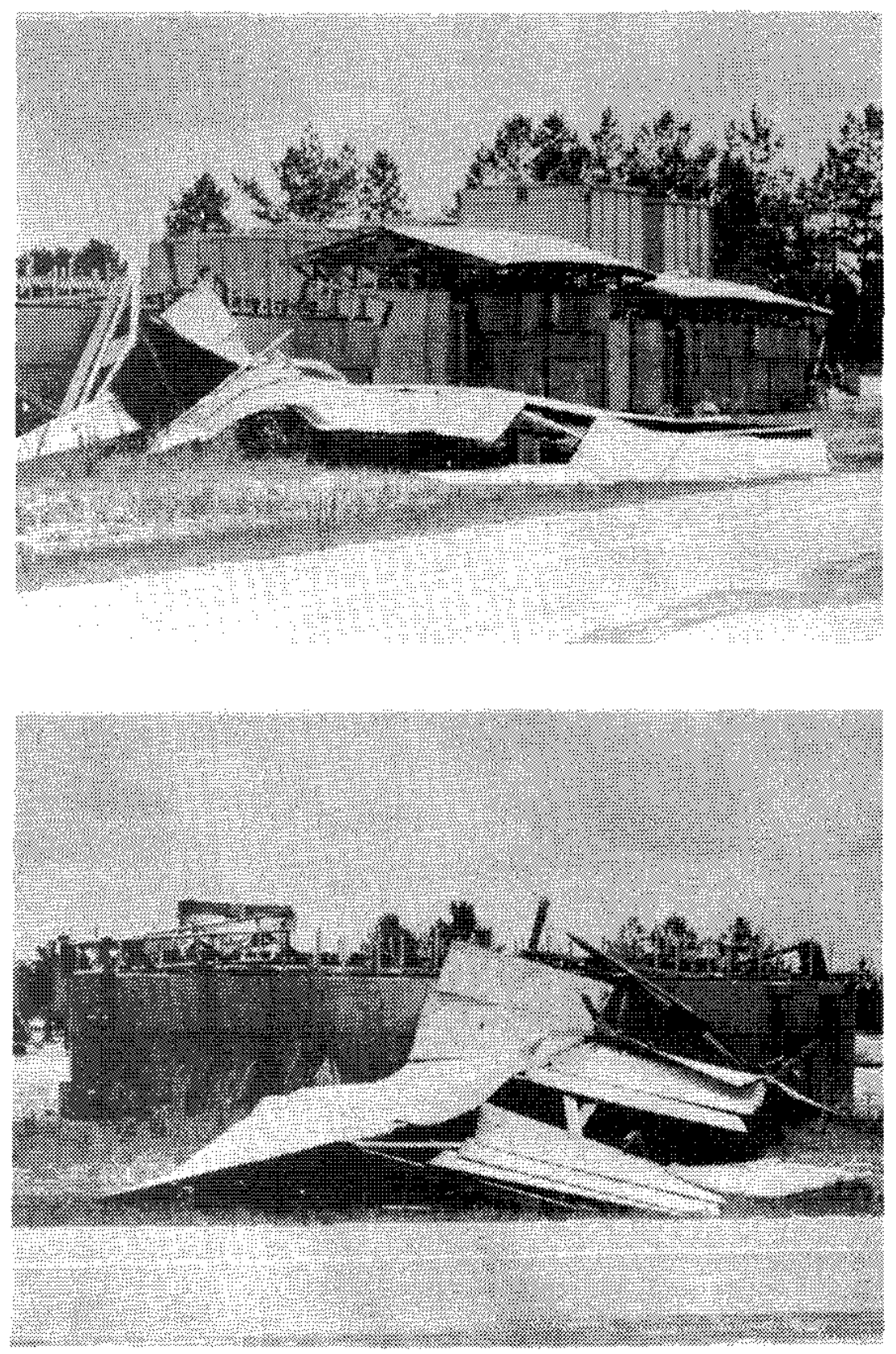

Finure 9. Bullding Danage From Tornado of May 28, 1976 

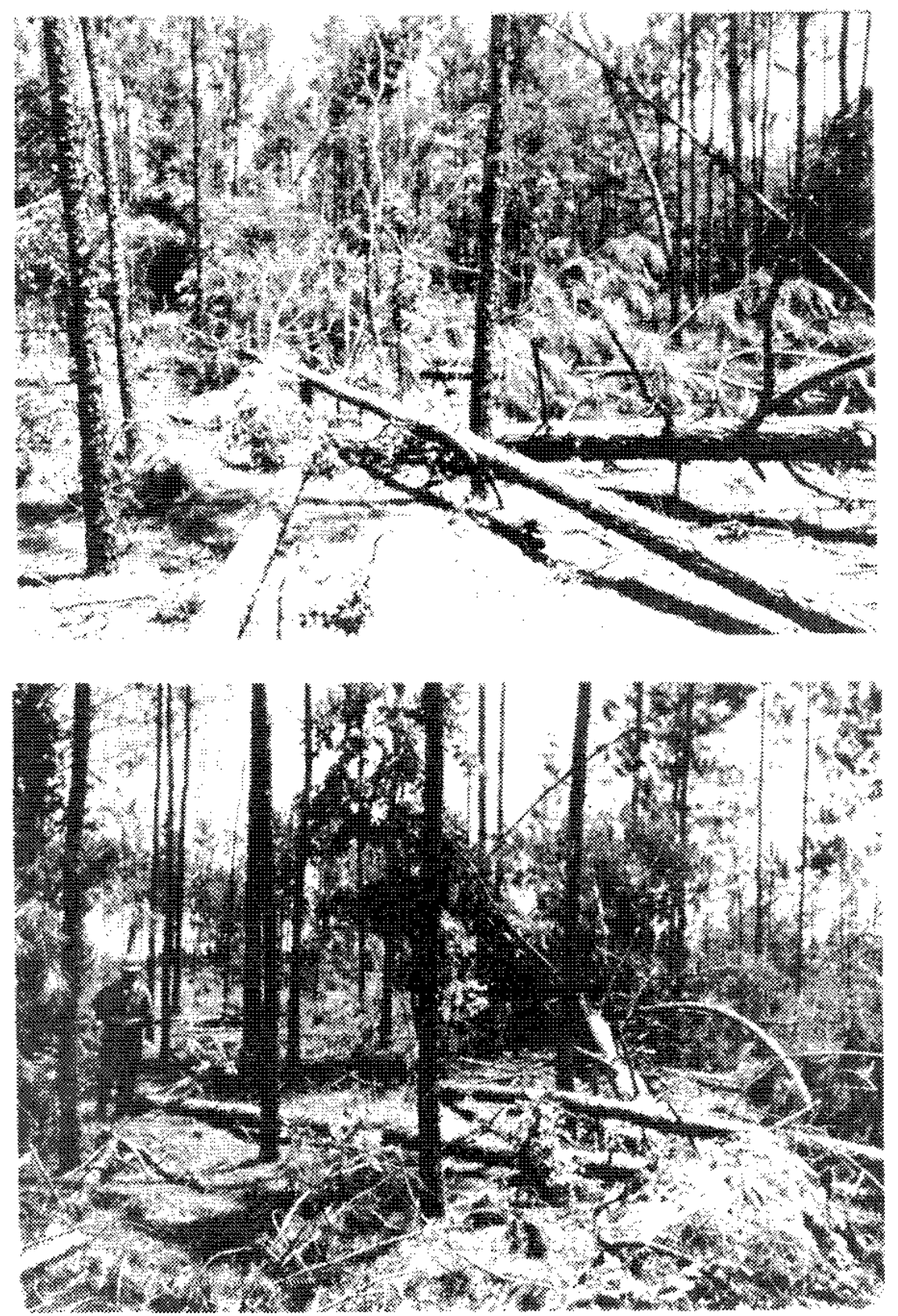

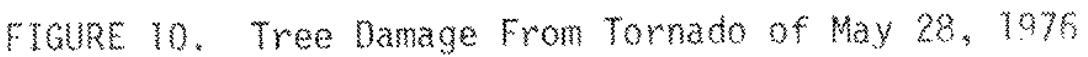



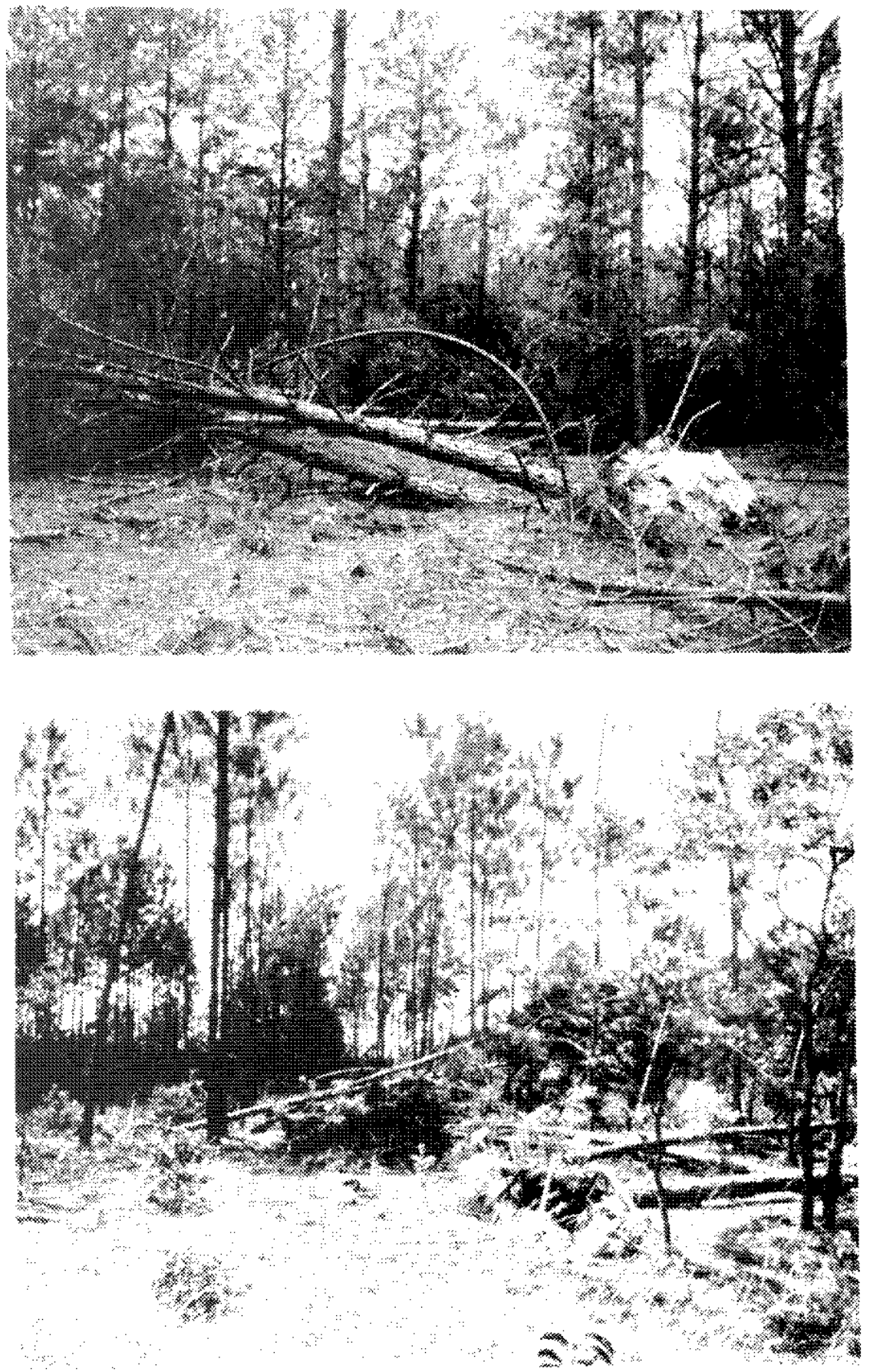

Frouke 1. Tree Danage From Tornado of July 2-4. 1976 